\title{
RHBDF2 Gene
}

National Cancer Institute

\section{Source}

National Cancer Institute. RHBDF2 Gene. NCI Thesaurus. Code C132322.

This gene plays a role in modulation of epidermal growth factor receptor signaling pathways. 